\title{
IMPACT OF EUTROPHICATION AND CLIMATE CHANGE ON Cd AND OTHER TRACE METAL DYNAMIC IN THE GULF OF RIGA, BALTIC SEA
}

\author{
Juris Aigars*\#, Rita Poikāne, Iveta Jurgensone, and Mintauts Jansons \\ Latvian Institute of Aquatic Ecology, LV-1048, Rīga, LATVIA \\ juris.aigars@Ihei.Iv \\ \# Corresponding author \\ Communicated by Viesturs Melecis
}

\begin{abstract}
The ability of $\mathrm{Cd}$ and other trace metals to be incorporated in living phytoplankton cells has been widely used to explain its dynamic in marine ecosystem. However, the discrepancy between results from water column studies and those from studies in sediments remain unexplained. This strongly suggests a need for study with a more interconnected approach in identification of the main governing factors of trace element dynamics. Therefore, we conducted this study, which linked sedimentary records of trace elements with particular emphasis on Cd with available supporting information from sediments and water column. The concentrations of $\mathrm{Cu}, \mathrm{Mn}, \mathrm{Cd}$ and $\mathrm{Cr}$ in sediments of the Gulf of Riga exhibited significant $(\mathrm{P}<0.01)$ positive relationships, while concentrations of $\mathrm{Al}$ and Ni had significant $(\mathrm{P}<0.01$ and $\mathrm{P}<0.05$, respectively) negative correlation with concentrations of TC. Concentrations of $\mathrm{Zn}, \mathrm{Pb}$ and $\mathrm{Fe}$ in sediments did not exhibit significant correlation with concentrations of total carbon (TC). The vertical profiles of concentrations of several elements indicated that their accumulation patterns in sediments have changed substantially over time in respect to that of TC. The magnitude of change varied substantially from retaining positive correlation but changing element ratio value, in case of $\mathrm{Cd}$, to complete shift from positive correlation to negative, in case of $\mathrm{Zn}$ and $\mathrm{Cu}$.
\end{abstract}

Key words: Gulf of Riga, trace metals in sediments.

\section{INTRODUCTION}

Over the past decades, worldwide as well as in the Baltic $\mathrm{Sea}$, trace metals, such as $\mathrm{Zn}, \mathrm{Cd}, \mathrm{Mn}, \mathrm{Cu}$ have been extensively studied in the marine environment, both as limiting nutrients (Sunda and Huntsman, 1998; Muller et al., 2003; Leblanc et al., 2005) and as toxicants (Schneider and Pohl, 1996; Leivuori and Vallius, 1998; Dippner and Pohl, 2004). During most of these studies, $\mathrm{Cd}$ has received specific attention, since although Cd usually is considered to be nonessential for biological processes or even toxic to marine organisms, it has the ability to become incorporated in living cells by specialised membrane proteins (Lee et al., 1995; Sunda and Huntsman, 1998), where it can become incorporated in some enzymes, for example substituting $\mathrm{Zn}$ (Morel et al., 1994; Cullen et al., 1999). It has been shown that under $\mathrm{Zn}, \mathrm{Mn}$ and Fe limitation conditions phytoplankton growth can be stimulated by Cd (Lee and Morel, 1995; Sunda and Huntsman 2000; Xu and Morel 2013), thereby boosting $\mathrm{Cd}$ uptake by phytoplankton. At the same time, it has been noted that under non-limiting concentrations the uptake of $\mathrm{Cd}$ by phytoplankton is proportional to its concentration in water (Connell and Sanders, 1999) and it has been even suggested that $\mathrm{Cd}$ as well as $\mathrm{Cu}$ and $\mathrm{Zn}$ uptake by phytoplankton can be controlled by non-metabolic process
(Miao et al., 2005). Thus, although there is still ongoing discussion on factors controlling $\mathrm{Cd}$ levels in phytoplankton, it is widely accepted that its behavior is nutrient like. Therefore, the temporal or spatial depletion of dissolved $\mathrm{Cd}$ concentrations (Bruland et al., 1978; Schneider and Pohl, 1996), or a significant increase in particular Cd concentrations in surface waters (Poikane et al., 2005, is usually attributed to $\mathrm{Cd}$ uptake by phytoplankton. In addition to that, $\mathrm{Cd}$ is known to remain in dissolved phase under oxic conditions (Pohl et al., 1998; Pohl and Hennings, 1999), thus excluding deposition to sediment surface, while adsorbed at the surface of mineral particles in well-oxygenated marine basins, such as the Gulf of Riga. Furthermore, sediment records of $\mathrm{Cd}$ in some sub-basins of the Baltic Sea (Leivuori et al., 2000) indicate that the $\mathrm{Cd}$ deposition rate has increased similarly to that of carbon over the last 50 to 100 years. However, evidence from the recent seasonal sediment trap study by Leivuori and Vallius (1998) indicates that Cd concentration is not correlated with carbon concentration in the settling phase.

This controversial observation led us to hypothesise that the $\mathrm{Cd}$ deposition rate in the Baltic Sea has been affected by changes in phytoplankton species composition, as evidenced by paleoecological studies (Olli et al., 2007). In or- 


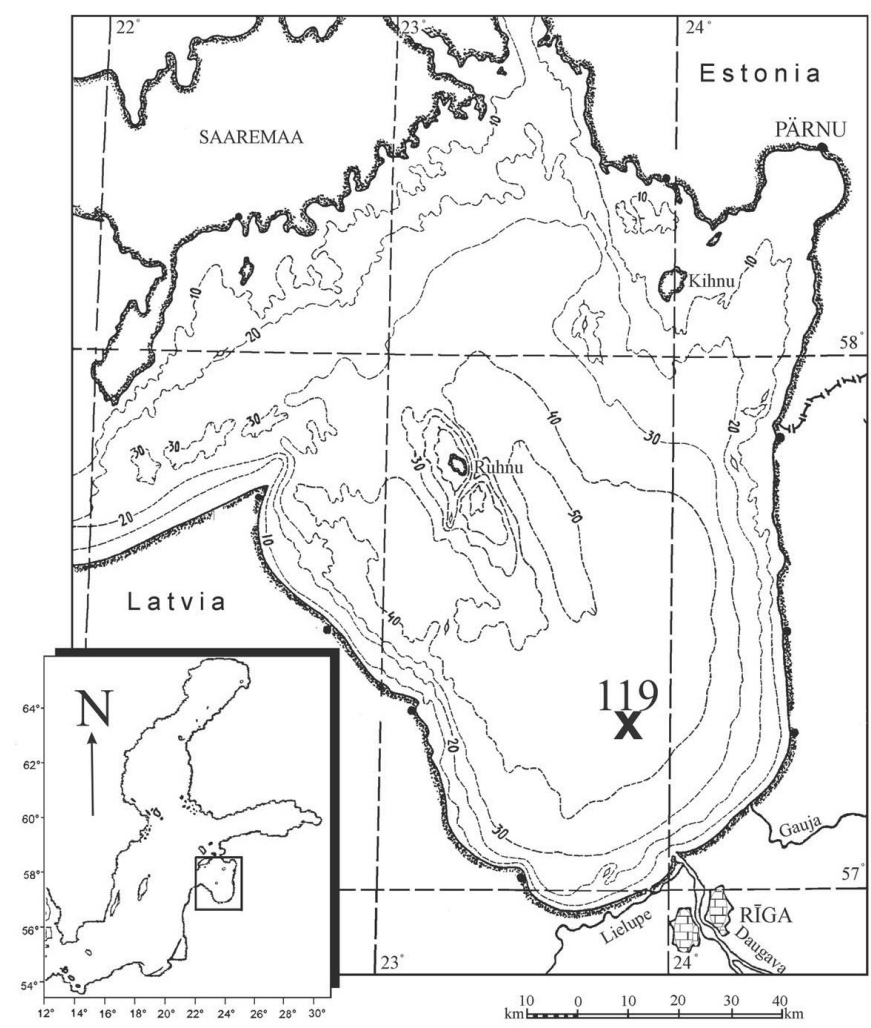

Fig. 1. The Gulf of Riga with location of sampling station marked by x. Inserted map in lower left corner shows the location of the gulf within the Baltic Sea.

der to test the hypothesis in this publication we determined trace metal concentrations in sediments sampled in the Gulf of Riga at locations with good coverage of supporting monitoring data.

\section{MATERIALS AND METHODS}

A site with $43 \mathrm{~m}$ depth (Fig. 1) located $\left(57^{\circ} 18^{\prime} \mathrm{N} ; 23^{\circ} 51^{\prime} \mathrm{E}\right)$ in the Gulf of Riga, which had good coverage of monitoring data, was chosen for this study. The average sediment accumulation rate $\left(0.04 \mathrm{~g} \mathrm{~cm}^{-2} \mathrm{yr}^{-1}\right.$ of dry matter) for this area was estimated by ${ }^{210} \mathrm{~Pb}$ dating method. For our study we used a 25-cm deep sediment core sampled in April 2003 using a modified Kajak type gravity corer (Blomqvist and Abrahamsson, 1985) equipped with an acrylic liner $(8 \mathrm{~cm}$ in diameter). The core was sliced in $1 \mathrm{~cm}$ intervals, freezedried and stored at the Latvian Institute of Aquatic Ecology. Total carbon (TC) and total nitrogen (TN) in sediments were determined by high temperature combustion (Elemental Analyzer Vario EL III), BSi was extracted with $1 \%$ $\mathrm{Na}_{2} \mathrm{CO}_{3}$ and determined by the molybdenum blue method (DeMaster, 1981). Samples for trace metal analysis were digested according to a modified total wet digestion method described by Hovind and Skei (1992) in a PTFE vessel with a mixture of sub-boiled nitric acid and suprapure hydrofluoric acid at $96{ }^{\circ} \mathrm{C}$ in a water bath for $2 \mathrm{~h}$. Dissolved samples were evaporated to wet salts and cooled; then $2 \mathrm{~cm}^{3}$ suprapure $30 \%(\mathrm{w} / \mathrm{w})$ hydrogen peroxide was added and vessels were heated to $50 \pm 5^{\circ} \mathrm{C}$ for a sufficiently long time for only wet salts to remain. After cooling, the samples were transferred and diluted with $10 \%(\mathrm{w} / \mathrm{w})$ sub-boiled nitric acid solution into volumetric flasks. $\mathrm{Al}, \mathrm{Fe}, \mathrm{Mn}$ and $\mathrm{Zn}$ in all samples were determined by flame-AAS (Varian Spectra AA 880). $\mathrm{Cd}, \mathrm{Cu}, \mathrm{Ni}, \mathrm{Pb}$ and $\mathrm{Cr}$ were determined by graphite furnace AAS (Varian Spectra AA 880Z) with Zeeman background correction. Precision for determination of $\mathrm{Al}$, $\mathrm{Fe}$ and $\mathrm{Mn}$ was $5 \%$, for $\mathrm{Zn}-10 \%$, for $\mathrm{Cd}$, $\mathrm{Ni}$ and $\mathrm{Pb}-$ $15 \%$, and for $\mathrm{Cu}$ and $\mathrm{Cr}-20 \%$. For quality control of trace metal measurements, sediment test material QTM063MS supplied for the QUASIMEME Laboratory Performance Studies was used as reference material.

Accumulation rates of elements $\left(\mathrm{g} \mathrm{m}^{-2} \mathrm{yr}^{-1}\right)$ were calculated from their concentrations in sediments and estimated average accumulation rate of sediments.

Supporting information and data from the water column (phytoplankton species composition and abundance) was obtained from the Latvian marine monitoring programme (Latvian Institute of Aquatic Ecology) and (particulate trace element concentrations in water columns and trace element concentration in the nepheloid layer) from a published research project (Poikane et al., 2005).

Linear correlation between variables was tested by using Pearson correlation approach. The slope was estimated by applying simple linear regression calculations.

\section{RESULTS}

The concentration range of measured elements in the sediment were $2.7-5.5 \% \mathrm{TC}, 0.33-0.65 \% \mathrm{TN}, 2.2-6.5 \% \mathrm{BSi}$, $0.22-1.37 \mathrm{mg} \mathrm{kg}^{-1} \mathrm{dw} \mathrm{Cd}, 931-3764 \mathrm{mg} \mathrm{kg}^{-1} \mathrm{dw} \mathrm{Mn}$, $40-51 \mathrm{mg} \mathrm{kg}^{-1} \mathrm{dw} \mathrm{Ni}, 80-100 \mathrm{mg} \mathrm{kg}^{-1} \mathrm{dw} \mathrm{Cr}, 4.6-5.8 \%$ Fe, 34-61 mg kg ${ }^{-1} \mathrm{dw} \mathrm{Pb}, 26-37 \mathrm{mg} \mathrm{kg}^{-1} \mathrm{dw} \mathrm{Cu}$ and 111-326 mg kg-1 dw Zn.

TC, BSi, Mn, Cd (Fig. 2) and TN concentrations significantly $(P<0.01)$ increased from deeper sediment layers to-

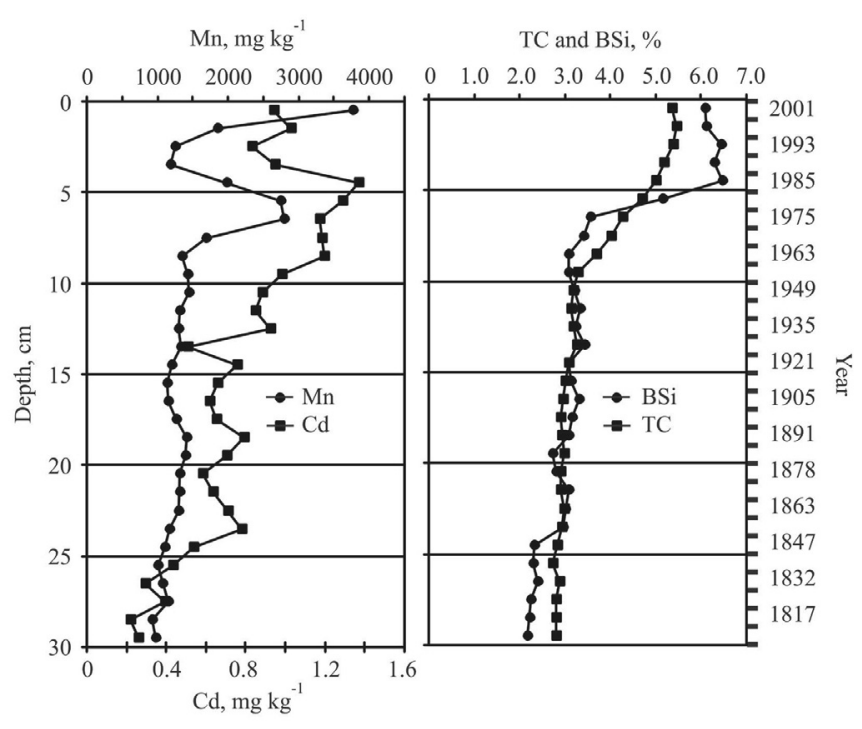

Fig. 2. Vertical profiles of $\mathrm{Mn}, \mathrm{Cd}, \mathrm{TC}$ and $\mathrm{BSi}$ in the sediments. 
wards the surface In the top 6-10 $\mathrm{cm}$, corresponding to about 1960, a gradual concentration increase of TC $($ slope $=$ $0.02 ; \mathrm{R}^{2}=0.8$ ) changed to more rapid increase (slope $=0.3$; $\mathrm{R}^{2}=0.99$ ) in recent sediments. Similarly, $\mathrm{Zn}, \mathrm{Cu}$, and $\mathrm{Cr}$ also showed increasing concentration, but which did not change in rate of increase. The concentrations of $\mathrm{Al}$ and $\mathrm{Ni}$ decreased towards the sediment surface, while $\mathrm{Fe}$ and $\mathrm{Pb}$ concentrations did not show trends.

As could be expected, the concentrations of nutrients (TN and $\mathrm{BSi})$, as well as most nutrient-like elements $(\mathrm{Cu}, \mathrm{Mn}$, $\mathrm{Cr}$ and $\mathrm{Cd})$, were significantly $(P<0.01)$ positively correlated with TC and significantly $(P<0.01)$ negatively correlated with $\mathrm{Al}$ (Table 1). Fe and $\mathrm{Zn}$, which are also usually considered to be elements used by phytoplankton, did not exhibit significant correlation with TC (Table 1). At the same time, accumulation rates of $\mathrm{Cu}$ and $\mathrm{Cr}$ were positively correlated with both accumulation rates of $\mathrm{TC}$ and $\mathrm{Al}$ (Table 2), indicating that $\mathrm{Cu}$ and $\mathrm{Cr}$ is deposited to the sea floor by particles of both abiotic and biotic origin. No such correlation was observed between accumulation rates of $\mathrm{Cd}$ and Al.

The increase of average accumulation rates in the periods prior to the 1960s, compared to the most recent period, was by $80 \%$ for TC, TN and Mn, $100 \%$ for BSi and $70 \%$ for Cd. $\mathrm{Cu}(20 \%)$ and $\mathrm{Zn}$ and $\mathrm{Cr}(10 \%)$ exhibited a much lower increase in accumulation rates, while the accumulation rates of $\mathrm{Al}, \mathrm{Fe}$ and $\mathrm{Ni}$ did not exhibit any detectable change. Consequently, substantial differences between ratios of accumulation rates of $\mathrm{TC}, \mathrm{Cu}, \mathrm{Cr}$ and $\mathrm{Zn}$ prior to and after the 1960s were observed. For example, the $\mathrm{Cu}$ accumulation

PEARSON CORRELATION COEFFICIENTS BETWEEN ELEMENT CONCENTRATIONS MEASURED IN A SEDIMENT CORE, $\mathrm{n}=30$

\begin{tabular}{|c|c|c|c|c|c|c|c|c|c|c|c|c|}
\hline & $\mathrm{Zn}$ & $\mathrm{Cu}$ & $\mathrm{Mn}$ & $\mathrm{Al}$ & $\mathrm{Cd}$ & $\mathrm{Cr}$ & $\mathrm{Ni}$ & $\mathrm{Pb}$ & $\mathrm{Fe}$ & $\mathrm{C}$ & $\mathrm{N}$ & $\mathrm{BSi}$ \\
\hline $\mathrm{Zn}$ & 1 & & & & & & & & & & & \\
\hline $\mathrm{Cu}$ & $0.347^{*}$ & 1 & & & & & & & & & \\
\hline $\mathrm{Mn}$ & 0.139 & $0.597^{* *}$ & 1 & & & & & & & & & \\
\hline $\mathrm{Al}$ & -0.020 & $-0.348^{*}$ & $-0.369^{*}$ & 1 & & & & & & & & \\
\hline $\mathrm{Cd}$ & $0.332^{*}$ & $0.902^{* *}$ & $0.599^{* *}$ & $-0.480^{* *}$ & 1 & & & & & & & \\
\hline $\mathrm{Cr}$ & 0.300 & $0.720^{* *}$ & $0.494^{* *}$ & -0.088 & $0.550^{* *}$ & 1 & & & & & & \\
\hline $\mathrm{Ni}$ & $0.329^{*}$ & -0.008 & -0.229 & $0.590^{* *}$ & -0.078 & 0.143 & 1 & & & & & \\
\hline $\mathrm{Pb}$ & $0.582^{* *}$ & $0.334^{*}$ & 0.129 & 0.063 & 0.198 & $0.478^{* *}$ & 0.188 & 1 & & & & \\
\hline $\mathrm{Fe}$ & $0.452^{* *}$ & 0.164 & 0.059 & 0.251 & 0.177 & 0.157 & $0.636^{* *}$ & $0.409^{*}$ & 1 & & & \\
\hline $\mathrm{TC}$ & 0.063 & $0.660^{* *}$ & $0.644^{* *}$ & $-0.707^{* *}$ & $0.677^{* *}$ & $0.510^{* *}$ & $-0.385^{*}$ & -0.033 & -0.203 & 1 & & \\
\hline $\mathrm{TN}$ & 0.036 & $0.633^{* *}$ & $0.631^{* *}$ & $-0.716^{* *}$ & $0.658^{* *}$ & $0.487 * *$ & $-0.394^{*}$ & -0.063 & -0.223 & $0.998^{* *}$ & 1 & \\
\hline $\mathrm{BSi}$ & 0.113 & $0.586^{* *}$ & $0.551^{* *}$ & $-0.748^{* *}$ & $0.631^{* *}$ & $0.460^{* *}$ & $-0.415^{*}$ & 0.063 & -0.116 & $0.951^{* *}$ & $0.951^{* *}$ & 1 \\
\hline
\end{tabular}

\footnotetext{
$* P \leq 0.05$.
}

** $P \leq 0.01$.

Table 2

PEARSON CORRELATION COEFFICIENTS BETWEEN ELEMENT ACCUMULATION RATES IN SEDIMENTS

\begin{tabular}{|c|c|c|c|c|c|c|c|c|c|c|}
\hline & $\mathrm{C}$ & $\mathrm{B}-\mathrm{Si}$ & $\mathrm{Cd}$ & $\mathrm{Zn}$ & $\mathrm{Al}$ & $\mathrm{Cu}$ & $\mathrm{Cr}$ & $\mathrm{Fe}$ & $\mathrm{Ni}$ & $\mathrm{N}$ \\
\hline $\mathrm{B}-\mathrm{Si}$ & $0.96^{* * *}$ & 1 & & & & & & & & \\
\hline $\mathrm{Cd}$ & $0.73^{* * *}$ & $0.67 * * *$ & 1 & & & & & & \\
\hline $\mathrm{Zn}$ & $0.57^{* *}$ & $0.51^{* *}$ & $0.69^{* * *}$ & 1 & & & & & & \\
\hline $\mathrm{Al}$ & 0.28 & 0.138 & 0.2 & $0.56^{* *}$ & 1 & & & & & \\
\hline $\mathrm{Cu}$ & $0.80^{* * *}$ & $0.69 * * *$ & $0.81^{* * *}$ & $0.85^{* * *}$ & $0.66^{* * *}$ & 1 & & & & \\
\hline $\mathrm{Cr}$ & $0.72^{* * *}$ & $0.61 * * *$ & $0.58^{* * *}$ & $0.77^{* * *}$ & $0.80^{* * *}$ & $0.92^{* * *}$ & 1 & & & \\
\hline $\mathrm{Fe}$ & $0.48^{* *}$ & 0.4 & $0.43^{*}$ & $0.73^{* * *}$ & $0.83^{* * *}$ & $0.76^{* * *}$ & $0.83^{* * *}$ & 1 & & \\
\hline $\mathrm{Ni}$ & $0.46^{*}$ & 0.34 & 0.37 & $0.65^{* * *}$ & $0.91 * * *$ & $0.77^{* * *}$ & $0.86^{* * *}$ & $0.93^{* * *}$ & 1 & \\
\hline $\mathrm{N}$ & $1.00^{* * *}$ & $0.96^{* * *}$ & $0.72^{* * *}$ & $0.55^{* *}$ & 0.27 & $0.79 * * *$ & $0.72^{* * *}$ & $0.47 * *$ & $0.46^{*}$ & 1 \\
\hline $\mathrm{Mn}$ & $0.67^{* * *}$ & $0.61 * * *$ & $0.60^{* * *}$ & $0.41^{*}$ & 0.17 & $0.55^{* *}$ & $0.49^{* *}$ & 0.32 & 0.21 & $0.67 * * *$ \\
\hline
\end{tabular}

$$
\begin{aligned}
& \text { * } \quad P \leq 0,050 \\
& \text { ** } \quad P \leq 0,010 \\
& \text { *** } P \leq 0.001
\end{aligned}
$$




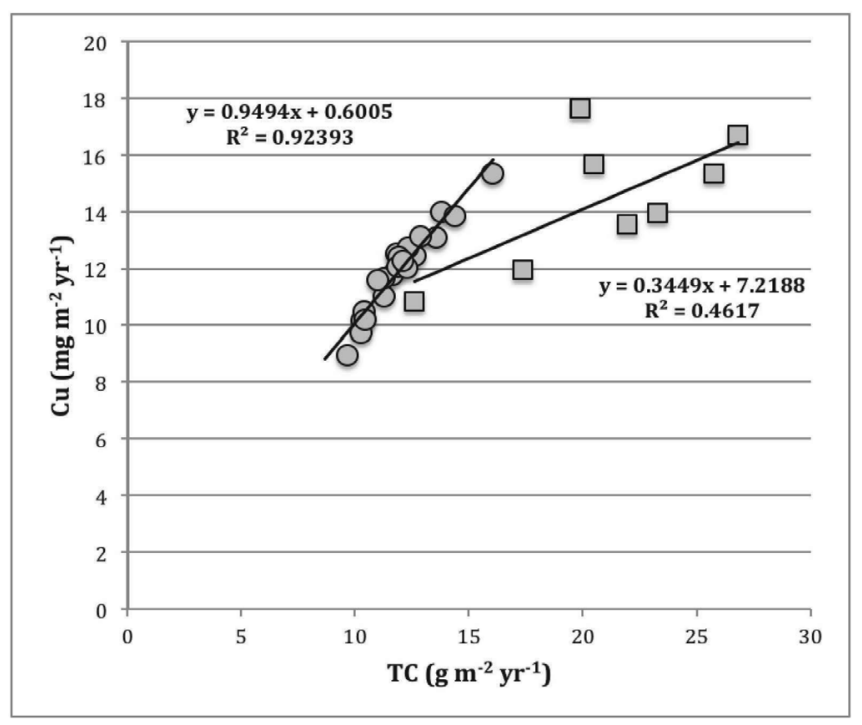

Fig. 3. $\mathrm{Cu}$ and $\mathrm{TC}$ accumulation rate in sediments. Circles represent the time period prior to the 1960 s, squares after.

rates demonstrated a very tight correlation with accumulation rates of TC up to 1960s (Fig. 3). Thereafter, the correlation remained positive, but was weaker. Furthermore, accumulation rates of $\mathrm{Zn}$ did not exhibit any significant correlation with accumulation rates of $\mathrm{TC}$ when the whole sediment core was considered. However, when the sediment core was divided in periods prior to and after the 1960s, clear correlation between accumulation rates of $\mathrm{Zn}$ and TC was observed (Fig. 4). The accumulation rates of $\mathrm{Cd}$ (Fig. 5) and Mn exhibited close correlation with accumulation rates of $\mathrm{TC}$, excepting in the top $4-5 \mathrm{~cm}$ sediments.

\section{DISCUSSION}

There are very few reliable measurements of trace element concentrations in Baltic Sea water (Schneider and Pohl, 1996; Dippner and Pohl, 2004). However, according to the collected data, the concentration levels observed in the water column are much higher than those considered to be limiting for phytoplankton growth (Lee and Morel, 1995). Therefore, we can assume that in the Baltic Sea enhanced uptake of $\mathrm{Cd}$ by phytoplankton under $\mathrm{Zn}, \mathrm{Fe}$ or $\mathrm{Mn}$ limiting conditions is not plausible and it can be assumed that $\mathrm{Cd}$ and possibly other trace element uptake is proportional to trace element concentrations in water, as shown by Connell and Sanders (1999) and Miao et al. (2005). The factors controlling this process are still poorly described. Furthermore, it has been shown that phytoplankton capacity to uptake trace elements varies depending on the species (Sunda and Huntsman, 1998; Ho et al., 2003). Smetacek (1980) and numerous later investigations have shown that major deposition of particulate material to sediment surface occurs after spring bloom. The spring bloom species composition and its changes have been of particular interest when analyzing accumulation patterns of elements. Trace element uptake experiments (Sunda and Huntsman, 1998; Ho et al., 2003) showed that both major spring phytoplankton bloom

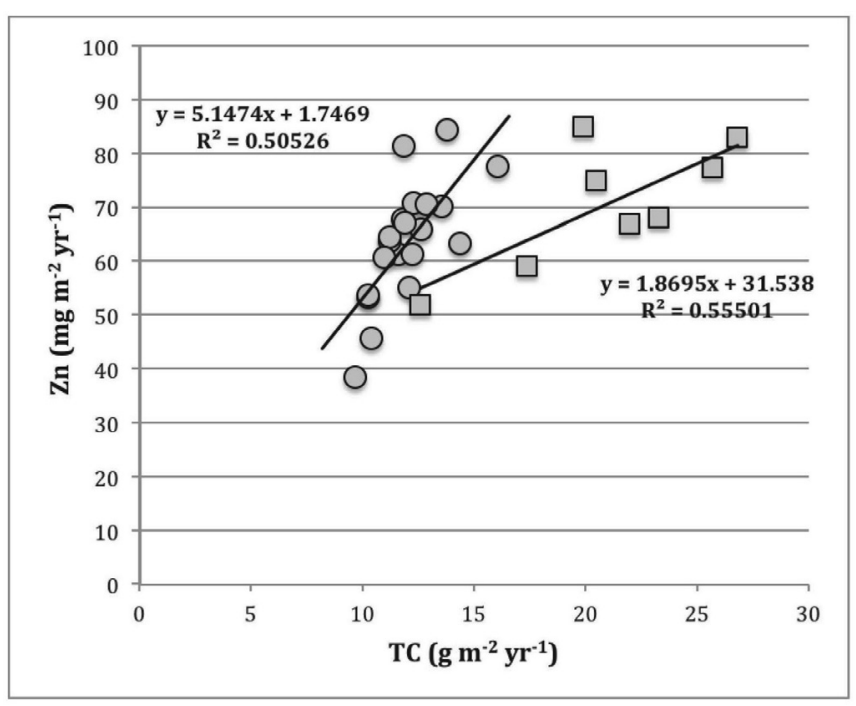

Fig. 4. $\mathrm{Zn}$ and TC accumulation rate in sediments. Circles represent the time period prior to the $1960 \mathrm{~s}$, squares after.

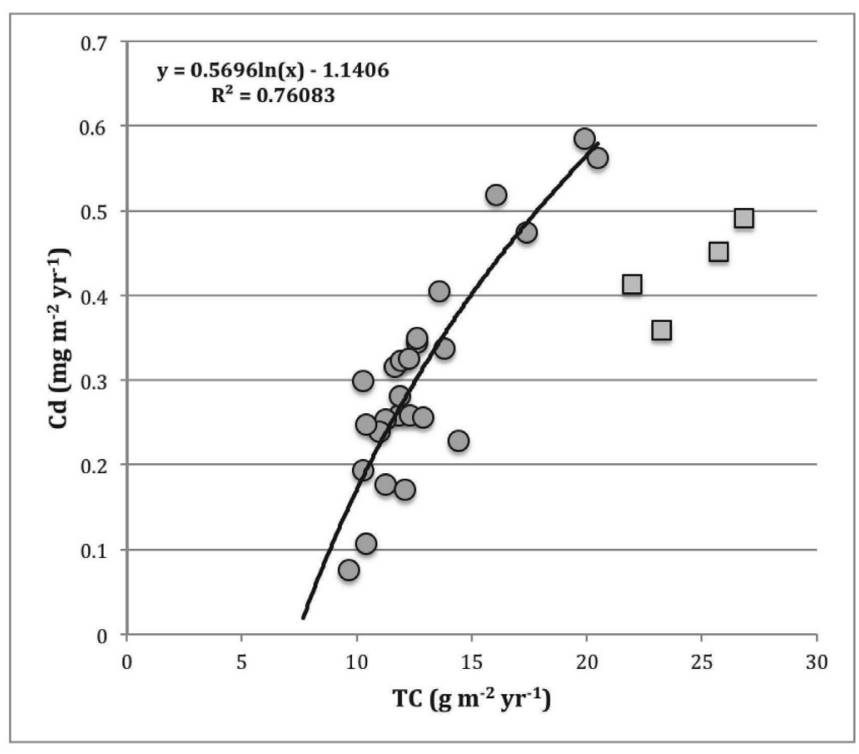

Fig. 5. Cd and TC accumulation rate in sediments. Circles represent time period prior to 1989 , squares after.

forming groups, diatoms and dinoflagellates, readily assimilate $\mathrm{Cd}$ and other nutrient-like trace elements. Therefore, we can assume that observations of our study, as well as those of earlier investigations (Poikane, 2008) showing positive correlation between nutrient-like trace element and carbon concentrations in sediments of the Gulf of Riga, reflect deposition of trace elements along with deposition of phytoplankton cells. However, this assumption cannot explain the shift in ratio between trace element and TC accumulation rates observed in our study, and therefore, we have to assume that other factors are controlling accumulation rates of trace elements.

The ratio $\mathrm{BSi}(\%)$ : TC (\%) ratio was relatively stable up to 1960s (0.96), then changed to 0.86 (1960s to 1980s) and then to 1.17 resulting in a $20 \%$ increase of BSi : TC concentration ratio by 1980 s. Since diatoms generally have a significantly lower content of trace elements than other 
phytoplankton groups (Ho et al., 2003) it seems likely that diatom-dominated bloom sedimentation would result in lower surface sediment enrichment by trace elements than dinoflagelate-dominated blooms. This is in agreement with results of sediment trap studies by Leivuori and Vallius (1998), which showed that the majority of annually deposited phytoplankton material was of diatom origin with low content of trace elements and the annual deposition of trace elements was not controlled by spring bloom deposition. Furthermore, relatively high concentrations of particulate $\mathrm{Cd}$ with no significant concentration increase for other trace elements have been observed in surface waters of the Gulf of Riga (Poikane et al., 2005) during a dinoflagellate (77\%, mostly Peridiniella catenata) dominated phytoplankton spring bloom in 2001 (Latvian Institute of Aquatic Ecology). This confirms that the observed increase of Cd concentration in sediments is controlled by dinoflagelate deposition. Therefore, the decrease in $\mathrm{Cd}$ concentration in sediments in proportion to TC, observed in the 1980, can be explained by shifts in relative proportions of material originating from diatom and dinoflagelate cells in favour of diatoms. The exact reason for this shift is still unclear, since monitoring is not regular and sufficiently frequent fully reflect spring bloom species composition monitoring. Possibly, substantial increase in nutrient loading to the sea occurred (Stålnacke et al., 1999) resulting in increased phytoplankton biomass, which might have caused changes in the diatom/dinoflagelate ratio during spring blooms. However, this cannot be supported by actual phytoplankton data. Furthermore, such change would be more gradual. Therefore, the abrupt shift concept proposed by Möllman et al. (2008) seems more likely to explain the abrupt change in the accumulation pattern of $\mathrm{Cd}$. As it has been shown by Möllman et al. (2008), the effect of climate resulted in shift of spring zooplankton biomass (ICES 2007), e.g., significant increase of biomass of the copepods Acartia spp. and Eurytemora affinis, in spring observed since 1985 (Diekmann and Möllmann, 2010). Since dinoflagelates usually form the second stage of the spring phytoplankton bloom then they would be more affected by earlier development of a zooplankton population than diatoms, and thus relative to diatom cell density, less dinoflagelate cells will be deposited on sediment surface due to increased grazing pressure. This is supported also by seasonal data on phytoplankton cell composition in the nepheloid layer during 2001 (Jurgensone, unpublished), which showed that more than $90 \%$ of identifiable cells in this layer were Thalassiosira baltica, even though the spring bloom was dominated by dinoflagellates.

Mn demonstrated and accumulation pattern similar to TC, and as observed also for $\mathrm{Cd}$, there was a lower accumulation rate in the uppermost $2-5 \mathrm{~cm}$. This might represent a specific case explained by its mobility under reduced conditions (Gobeil et al., 1997; Kuzyk et al., 2011). There have been no direct measurements of redox condition that would allow to describe its long term dynamics in Gulf of Riga sediments. However, during the late 1980s-1990s, the overlying water layer above sediments experienced a severe ox-

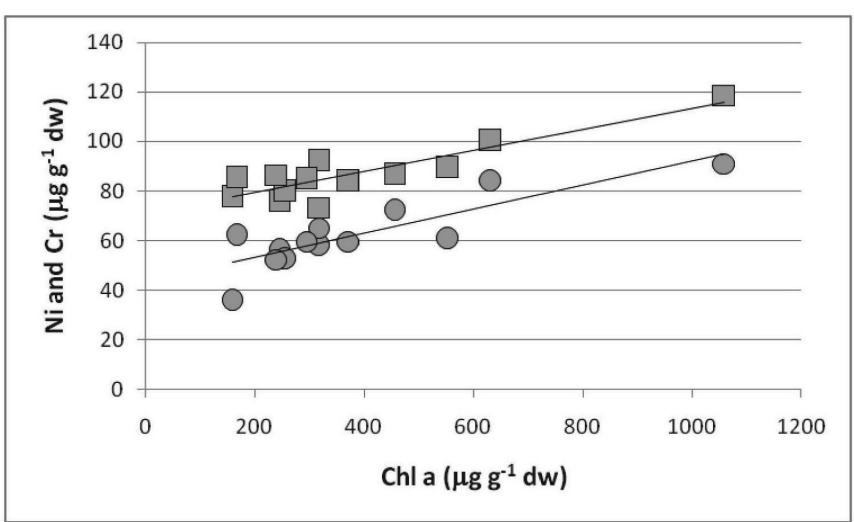

Fig. 6. Ni (circles) and $\mathrm{Cr}$ (squares) concentration correlation with chlorophyl a $\left(\mathrm{R}^{2}=0.7\right.$ and 0.8 , respectively) in nepheloid layer from April to October 2002 .

ygen deficit, which certainly influenced redox conditions of the surface sediments of the Gulf of Riga. Therefore, we can assume that during that period Mn was extensively released from sediments due to unfavourable redox conditions. With reestablishment of favourable redox conditions, re-adsorbtion of Mn on would have been promoted.

The shift in accumulation patterns of $\mathrm{Zn}, \mathrm{Cu}$ and $\mathrm{Cr}$ that occurred in the 1960s cannot be explained by increased zooplankton grazing pressure. The very slight (10-20\%) increase in accumulation rates as well as significant $(P<$ $0.001)$ correlation of accumulation rates of these elements and $\mathrm{Al}$ might suggest that the material containing these elements, which is deposited on the sediment surface, has abiotic origin. However, earlier investigations (e.g. Sunda and Huntsman 1998; Ho et al., 2003) indicate that phytoplankton cells assimilate these elements, and this was shown also in our study by a positive correlation with TC. Furthermore, significant positive chlorophyll a correlation with $\mathrm{Ni}\left(\mathrm{R}^{2}=0.7\right)$ and $\mathrm{Cr}\left(\mathrm{R}^{2}=0.8\right)$ (Fig. 5) in the nepheloid layer sampled during April - October 2002 (data from Poikane et al., 2005) strongly suggested that these elements were most likely incorporated in the bloom forming species Chaetoceros wighamii cells and were deposited along with them. Therefore, we suggest that in the case of $\mathrm{Zn}, \mathrm{Cu}$, and $\mathrm{Cr}$, and to some extent also $\mathrm{Ni}$, the major source for accumulation in sediments has abiotic material, while material of biotic origin, including detritus (Leivuori and Vallius, 1998), has secondary importance.

\section{ACKNOWLEDGMENTS}

The study was supported by grant of Latvian Council of Science, "Development of conceptual integrated model of socioeconomic biodiversity pressures and drivers and impacts for the long-term socioecological research platform of Latvia" (Ref. Nr. 10.0004).

\section{REFERENCES}

Anonymous (2007). Report of the ICES/HELCOM Working group on integrated assessments of the Baltic Sea (WGIAB), 12-16 March 2007, Hamburg, Germany. ICES CM 2007/BCC:04. 71 pp. 
Blomqvist, S., Abrahamsson, B. (1985). An improved Kajak-type gravity core sampler for soft bottom sediments. Schweiz. Z. Hydrol., 47, 81-84.

Bruland, K. W., Knauer, G. A., Martin, J. H. (1978). Cd in northeast Pacific waters. Limnol. Oceanogr., 23, 618-625.

Connell, D. B., Sanders, J. G. (1999). Variation in cadmium uptake by estuarine phytoplankton and transfer to the copepod Eurytemora affinis. Mar. Biol., 133, 259-265.

Cullen, J. T., Lane, T. W., Morel, F. M. M., Sherrell, R. M. (1999). Modulation of $\mathrm{Cd}$ uptake in phytoplankton by seawater $\mathrm{CO}_{2}$ concentration. Nature, 402, 165-166.

DeMaster, D. J. (1981). The supply and accumulation of silica in the marine environment. Geochim. Cosmochim. Acta, 45, 1715-1732.

Diekmann, R., Möllmann, C. (Eds.) (2010). Integrated ecosystem assessments of seven Baltic Sea areas covering the last decades. ICES Cooperative Research Report, No. 302.90 pp.

Dippner, J. W., Pohl, C. (2004). Trends in heavy metal concentrations in the Western and Central Baltic Sea waters detected by using empirical orthogonal function analysis. J. Mar. Syst., 46, 69-83.

Gobeil, C., Macdonald, R. W., Sundby, B. (1997). Diagenetic separation of cadmium and manganese in suboxic continental margin sediments. Geochim. Cosmochim. Acta, 61, 4647-4654.

Ho, T.-Y., Quigg, A., Finkel, Z. V., Milligan, A. J., Falkowski, P. G., Morel, F. M. M. (2003). The elemental composition of some marine phytoplankton. J. Phycol., 39, 1145-1159.

Hovind, H., Skei, J. (1992). Report of the second ICES intercomparison exercise on the determination of trace metals in suspended particulate matter. ICES Coop. Res. Rep., 184, 31 pp.

Kuzyk, Z. Z. A., Macdonald, R. W., Stern, G. A., Gobeil, C. (2011). Inferences about the modern organic carbon cycle from diagenesis of redox-sensitive elements in Hudson Bay. J. Mar. Syst., 88, 451-462.

Lee, J. G., Roberts, S. B., Morel, F. M. M. (1995). Cadmium: A nutrient for the marine diatom Thalassiosira weissflogii. Limnol. Oceanogr., 40, 1056-1063.

Leblanc, K., Hare, C. E., Boyd, P. W., Bruland, K. W., Sohst, B., Pickmere, S., Lohan, M. C., Buck, K., Ellwood, M., Hutchins, D. A. (2005). Fe and Zn effects on the Si cycle and diatom community structure in two contrasting high and low-silicate HNLC areas. Deep-Sea Res. I, 52, 1842-1864.

Lee, J. G., Morel, F. M. M. (1995). Replacement of zinc by cadmium in marine phytoplankton. Mar. Ecol. Progr. Ser., 127, 305-309.

Leivuori, M., Vallius, H. (1998). A case study of seasonal variation in the chemical composition of accumulating suspended sediments in the central Gulf of Finland. Chemosphere, 36, 2417-2435.
Leivuori, M., Jokšas, K., Seisuma, Z., Kulikova, I., Petersell, V., Larsen, B., Pedersen, B., Floderus, S. (2000). Distribution of heavy metals in sediments of the Gulf of Riga, Baltic Sea. Boreal Env. Res., 5, 165-185.

Miao, A.-J., Wang, W.-X., Juneau, P. (2005). Comparison of Cd, Cu, and Zn toxic effects on four marine phytoplankton by pulse-amplitude-modulated fluorometry. Environ. Toxicol. Chem., 24, 2603-2611.

Morel, F. M., Reinfelder, J. R., Roberts, S. B., Chamberlain, C. P., Lee, J. G., Yee, D. (1994). Zn and carbon co-limitation of marine phytoplankton. $\mathrm{Na}$ ture, 369, 740-742.

Möllman, C., Müller-Karulis, B., Kornilovs, G., St John, M. A. (2008). Effects of climate and overfishing on zooplankton dynamics and ecosystem structure: Regime shifts, trophic cascade, and feedbacks loops in a simple ecosystem. ICES J. Mar. Sci., 65(3), 302-310.

Muller, F. L. L., Jacquet, S., Wilson, W. H. (2003). Biological factors regulating the chemical speciation of $\mathrm{Cu}, \mathrm{Zn}$, and $\mathrm{Mn}$ under different nutrient regimes in a marine mesocosm experiment. Limnol. Oceanogr., 48, 2289-2302.

Pohl, C., Hennings, U., Petersohn, I., Siegel, H. (1998). Trace metal budget, transport, modification and sink in the transition area between the Oder and Peene rivers and southern Pomeranian Bight. Mar. Pollut. Bull., 36, 598-616.

Pohl, C., Hennings, U. (1999). The effect of redox processes on the partitioning of $\mathrm{Cd}, \mathrm{Pb}, \mathrm{Cu}$ and $\mathrm{Mn}$ between dissolved and particulate phases in the Baltic Sea. Mar. Chem., 65, 41-53

Poikane, R., Carstensen, J., Dahllöf, I., Aigars, J. (2005). Distribution patterns of particulate trace metals in the water column and nepheloid layer of the Gulf of Riga. Chemosphere, 60, 216-225.

Poikāne, R. (2008). Suspendēto daḷiņu un nogulumu loma metālisko elementu apritē Rìgas līcī [Role of suspended particles and sediment in the turnover of metallic elements in the Gulf of Riga]. LU Akadēmiskais apgāds. Ph.D. Thesis. ISBN 978-9984-802-97-8. 156 lpp.

Schneider, B., Pohl, C. (1996). Time series for dissolved cadmium at a coastal station in the Western Baltic Sea. J. Mar. Syst., 9, 159-170.

Smetacek, V. (1980). Annual cycle of sedimentation in relation to plankton ecology in western Kiel Bight. Ophelia. Suppl., 1, 65-76.

Stålnacke, P., Grimvall, A., Sundblad, K., Tonderski, A. (1999). Estimation of riverine loads of nitrogen and phosphorus to the Baltic Sea, 1970-1993. Environ. Monitor. Ass., 58, 173-200.

Sunda, W. G., Huntsman, S. A. (1998). Processes regulating cellular metal accumulation and physiological effects: Phytoplankton as model systems. Sci. Total Environ., 219, 165-181.

Sunda, W. G., Huntsman, S. A. (2000). Effect of Zn, Mn, and Fe on Cd accumulation in phytoplankton: Implications for oceanic Cd cycling. Limnol. Oceanogr., 45, 1501-1516.

Xu, Y., Morel, F. M. (2013). Cadmium in marine phytoplankton. Met Ions Life Sci., 11, 509-528. Doi: 10.1007/978-94-007-5179-8_16.

Received 25 March 2014

\section{EITROFIKĀCIJAS UN KLIMATA MAIN̦AS IETEKME UZ Cd UN CITU METĀLU ELEMENTU PĒDU DINAMIKU BALTIJAS

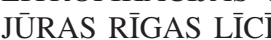

Fitoplanktona spēja iesaistìt $\mathrm{Cd}$ šūnā ir plaši izmantota lai skaidrotu Cd dinamiku jūras ekosistēmās. Tai pašā laikā ir novērotas analīžu rezultātu atškirības ūdenī un sedimentos, kuras līdz šim nav izskaidrotas. Tas nosaka nepieciešamību veikt pētījumu, kurā tiktu sasaistīti galvenie pēdu elementu dinamiku kontrolējošie faktori. Šajā pētījumā tika saistīts pēdu elementu vertikālais sadalījums sedimentos ar pieejamo atbalstošo informāciju no sedimentiem un ūdens kolonnu, īpašu uzmanību pievēršot Cd. Rīgas līča sedimentos novērotās Cu, Mn, Cd un Cr koncentrācijas uzrāda nozīmīgu $(P<0.01)$ pozitīvu korelāciju ar TC (kopējais ogleklis). Tai pašā laikā Al un Ni uzrāda nozīmīgu $(P<0.01)$ negatīvu korelāciju ar TC. Savukārt $\mathrm{Zn}, \mathrm{Pb}$ un Fe koncentrācijas sedimentos neuzrāda nozīmīgu korelāciju ar TC. Vairāki no apskatītajiem elementiem skaidri parādīja, ka laika gaitā ir būtiski mainījušies to akumulācijas režīmi attiecībā pret TC akumulācijas režīmu. Izmaiṇu lielums ir atškirīgs atškirīgiem elementiem. 